Document downloaded from:

http://hdl.handle.net/10251/147625

This paper must be cited as:

Vargas-Mendoza, NY.; Lloria, MB.; Salazar Afanador, A.; Vergara Domínguez, L. (2018). Effect of exploitation and exploration on the innovative as outcomes in entrepreneurial firms. International Entrepreneurship and Management Journal. 14(4):1053-1069. https://doi.org/10.1007/s11365-018-0496-5

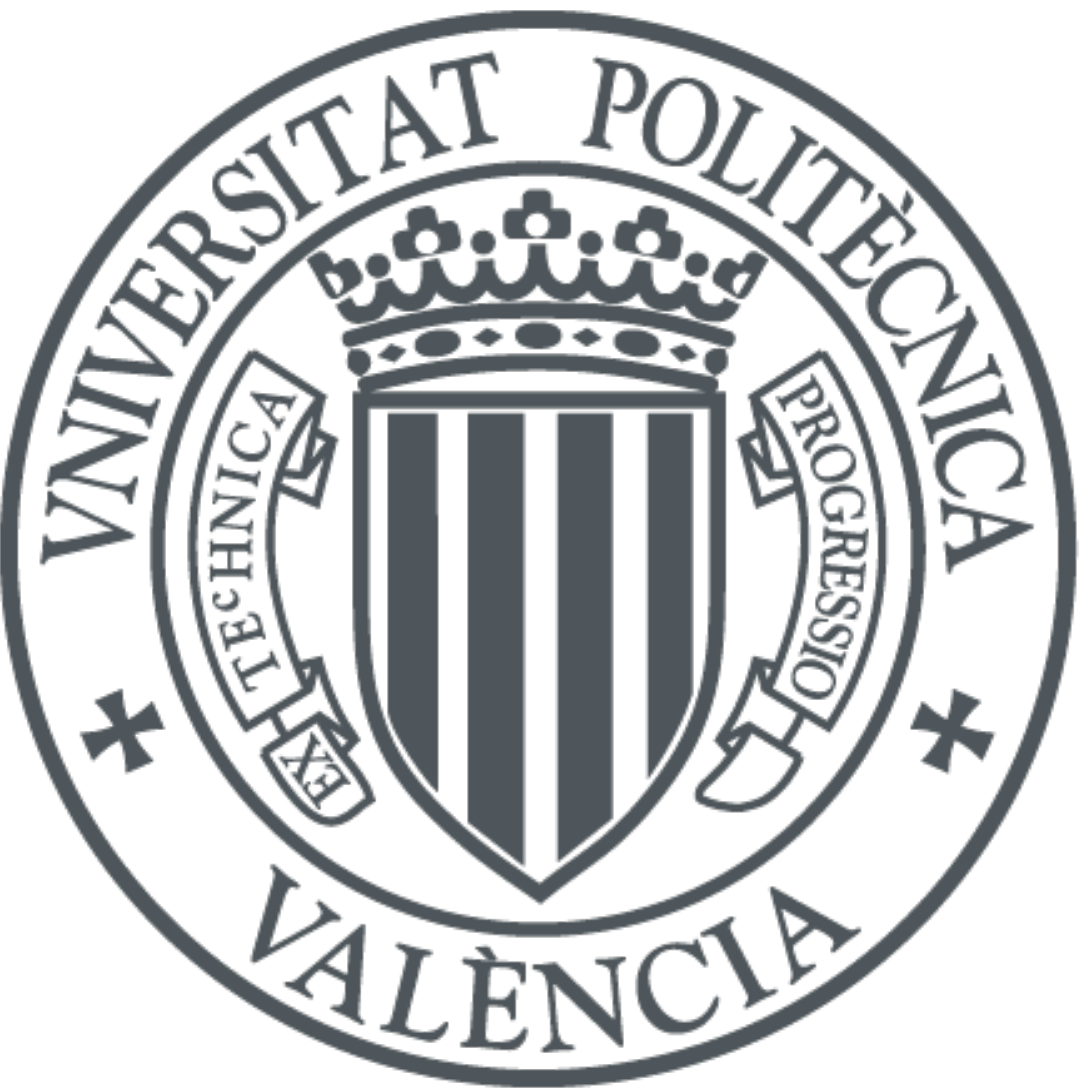

The final publication is available at

https://doi.org/10.1007/s11365-018-0496-5

Copyright Springer-Verlag

Additional Information 


\title{
Effect of exploitation and exploration on the innovative as outcomes in entrepreneurial firms
}

\author{
Nancy Vargas ${ }^{1}$, M. Begoña Lloria ${ }^{2}$, Addisson Salazar ${ }^{1}$, Luis Vergara ${ }^{1}$ \\ ${ }^{1}$ Universitat Politècnica de València, Instituto de Telecomunicaciones y Aplicaciones Multimedia \\ ${ }^{2}$ Universitat de València, Departamento de Dirección de Empresas
}

\begin{abstract}
The main aim of this study is to establish the effect of the Exploitation and Exploration; and the influence of these learning flows on the Innovative Outcome (IO). The Innovative Outcome refers to new products, services, processes (or improvements) that the organization has obtained as a result of an innovative process. For this purpose, a relationship model is defined, which is empirically contrasted, and can explains and predicts the cyclical dynamization of learning flows on innovative outcome in knowledge intensive firms.

The quantitative test for this model use the data from entrepreneurial firms biotechnology sector. The statistical analysis applies a method based on variance using Partial Least Squares (PLS).

Research results confirm the hypotheses, that is, they show a positive dynamic effect between the Exploration and the Innovative as outcomes. In the same vein, they results confirm the presence of the cyclic movement of innovative outcome with the Exploitation.
\end{abstract}

Keywords: learning flows, exploitation, exploration, innovative outcome, innovation, knowledge creation

\section{Introduction}

For decades, the Research and Development (R\&D) has been identified as the business function (business activity's) that most directly helps to create new products, services and processes, and therefore represents the fundamental basis for promoting the innovative capacity of firms (Cohen and Levinthal 1989; Ibarra 1993). Likewise, organizational learning is considered as the process that helps increase the capacity to generate and absorb knowledge in the organization and, as a consequence, allows to improve the impact of R\&D activities by increasing the ability to convert knowledge in new products, services and processes (Cohen and Levinthal 1989; Crossan and Apaydin 2010; Crossan et al. 1999; Damanpour and Aravind 2012; Damanpour and Shanthi 2001; Decarolis and Deeds 1999; Tansky et al. 2010; Iebra et al. 2011, Jiménez-Jiménez and Sanz-Valle 2011; among others). 
In these innovative processes, there is a need to share knowledge among the members of the organization (Huang et al. 2008; Lin 2007; Nonaka and Takeuchi 1995; Nonaka and von Krogh 2009). People often have a natural resistance to sharing what they know but, even if they are willing to do so, knowledge, especially the tacit, does not flow easily, but sharing it is a complex task on the part of the individual (Ardichvili 2008). In many instances, deliberate management interventions are required to facilitate and encourage learning, and to promote knowledge flow and sharing in a systematic way (Ardichvili 2008; Hsu 2006 and 2008; Ipe 2003).

The value of creating and sharing knowledge, and generating the associated learning flows between individuals and the organization to obtain innovation results, leads to this area having a special interest in research (Brachos et al. 2007; Cho 2007; Crossan and Apaydin 2010; Ganter and Hecker 2013; 2014; Parida et al. 2016; Sideler de alwis and Harman 2008; Teece 2012; Vargas and Lloria 2017; Vargas et al. 2016).

Although there are several studies that try to relate learning with innovation (Amara et al. 2008; Alegre and Chiva 2008; Alwis and Harmann 2008; Balthazards 2004; Dupuy 2004; Lansisalmi et al., 2006), there are few works that study the relationship in a direct way. Other works propose theoretical models that are novel but that do not come to be empirically contrasted in qualitative or quantitative studies.

Therefore, in this research we will try to study the impact of learning flows, specific the Exploration and Exploitation, on the variable Innovative Outcome (IO). For this purpose, a novel theoretical model of relationships is defined that will be contrasted empirically.

The paper presents a classic structure. We first present the theoretical framework where the Exploration and Exploitation, and the IO variable are defined; and study their relationships that will be translated into a theoretical model. Then, the hypotheses to be contrasted. These hypotheses are contrasted in a quantitative research of Spanish firms in the biotechnology sector. Finally, the results, the discussion and the most relevant conclusions, as well as some of the main limitations and future lines of research are presented.

\section{Learning flows and Innovation}

The concept of learning flow is known as the knowledge transfer and sharing within and across the boundaries of the organization. Learning, for its part, is a condition for the sustained change in the state of knowledge of an individual or an organization, change that refers both to the qualities of knowledge that is possessed, as well as the degree of experience with which it is known and can act on the known. It is a term that span cognitive and behavioral components linked to knowledge (Argyris and Schön 1978; Crossan et al. 1999 among others). According to this conception, organizational learning represents the transformation of both the way of thinking things (cognitive aspects of knowledge) and the way things are done in the organization (aspects related to behavior).

In March (1991), we enter into the types of flows. The first, is related to exploration. It is the transfer of learning from individuals and groups that becomes embedded or institutionalized in the organization, in the form of systems, structures, strategies and procedures (Hedberg 1981, Shrivastava 1983). On the other hand, is related to exploitation (March 1991) and in the way institutionalized learning affects individuals and groups. 
The Strategic Learning Assessment Map (SLAM) considers organizational learning as a dynamic process, where the present nature of the exploitation or feedback and the exploration or feedforward processes creates a tension. This implies that, in addition to the processes that encompass learning from the individuals and groups of the organization, the learning that has been institutionalized feeds back and impacts on individual learning and group learning (Crossan et al. 1999).

Also, the immersed learning systems in the organization are the result of the dynamic interaction between the dimensions of the Exploitation and Exploration learning flows, which elaborate, sustain or contradict the current knowledge inventories that form part of the organization (Decarolis and Deeds 1999; Hedlund and Nonaka 1993; Laperrière and Spence 2015; Moskaliuk, et al. 2016; Sanchez and Heene 1997). The dual orientation of learning flows represents the need to balance the tension between continuity and change. That is, flows between the different levels of learning generate tension between the processes of knowledge exploration and processes of knowledge exploitation (March 1991).

It is considered that the organizational learning, in its different levels, has a double purpose: the first purpose is to promote the variation of knowledge within the organization; and the second, is to produce new knowledge about the knowledge that exists in the organization. As a consequence, exploratory and exploitative flows are the essential engine of the dynamic evolution of knowledge between the different levels - individual, group and organization - of learning, so as Crossan et al. (1999: 522) establish: "Recognizing and maintaining the tension between exploration and exploitation is one of the critical challenges of renewal and, therefore, a central requirement of theories about learning in the organization."

The conception of learning as a dynamic flow brings with it the possibility that these flows may be limited. A dynamic theory of organizational learning recognizes that there might be "bottlenecks" in the organization's ability to absorb Exploration (Cohen and Levinthal 1990). This implies that changes in individual learning, and the pressures for innovation in new products, services and processes, could accumulate if the organization does not have the capacity to absorb the new knowledge.

The central aspect of the distinction between exploration and exploitation processes and its relations with innovation lies in revealing whether it is better for the organization to adopt an orientation that allows it to use its knowledge in the search for improvements within an established framework. Exploitation; or whether, on the contrary, it is preferable to pursue a renewed orientation of Exploration knowledge. In the first case, it is considered that knowledge flows from the organization, affecting the groups and, directly or through the latter, on individual knowledge; in the second case, knowledge flows from the individual to the group to transcend the organization (Kane and Alavi 2007). In any case, organizational learning systems must refine these flows in order to maximize the organization's innovative outcomes (Jenkin 2013). From here, the relevance of studying how and in what way learning flows impact on innovation outcomes are demonstrated. 


\section{Innovative as Outcome (IO)}

Wallin and von Krogh (2010) define innovation as a process that involves the creation of relevant knowledge about market trends, as well as the development of new technologies and knowledge necessary to carry out scientific and technical advances. This new knowledge can be used to develop something different and useful; That is, novel ideas that are transformed into new products, services and processes. From this, it follows that innovation is focused on knowledge and, therefore, innovation can't occur without knowledge (Nonaka and Takeuchi 1995; Nonaka and von Krogh 2009).

The results of innovative processes usually occur with the development of various outputs, which can vary in different ways. Crossan and Apaydin (2010) argue that the Innovative Outcome (IO) is the end point of a scientific search; and can be defined as new products, services or processes (or improvements) that the organization has obtained as a result of an innovative process. It is usually the key dependent variable in empirical studies related to innovation.

Going deeper into the concept, and according to Crossan and Apaydin (2010), the IO contemplates five dimensions: Referent, Form, Magnitude, Type and Nature. The first dimension, Reference, establishes the point of reference that defines innovation as a result, which may be new to the firm, new to the market or new to the industry. As for Form, the literature distinguishes three types of innovation: innovation in product or service, innovation in processes and innovation in the business model (Wang and Ahmed, 2004 p.304). The Magnitude dimension indicates the degree of novelty of the IO in relation to an existing result that has a high level of quality. On the fourth dimension, Type, Gopalakrishnan and Damanpour (1997) distinguish between technical innovations and administrative innovations. Technical innovations include products, processes and technologies that are used to produce the products or provide services directly related to the basic work activity of an organization. On the other hand, the administrative innovations are related to the basic activity of work and, more directly, they are related to aspects of management as the organizational structure, the administrative procedures and of the human resources. Finally, the Nature dimension refers to the type of innovation that, to a largely, is usually tacit nature and can remain in the organization without articulation.

Having defined what is understood by IO and its nature known, it may be interesting to link the IO with the business benefit to address if and how innovation creates value. According to the literature, the capacity for innovation is the most important determinant of performance in business profits. It is based on a positive relationship between firm innovation and profitability measures in order to generate profits (Alegre and Chiva 2008, Calantone et al. 2002, Mone et al. 1998; Ramadani et al. 2017). There have been several studies that have linked both aspects. Cooper (2000), for example, studied the relationship between new product strategies and the benefits of the new product. Klomp and Van Leeuwen (2001), through a feedback model, established a positive relationship between process innovation and benefits, using as a measure the profits of sales, sales per worker and worker growth. Jiménez-Jiménez and Sanz-Valle (2011), in a similar study, showed how the organizational learning and innovation variables contribute positively to the performance. Finally, Matikainen et al. (2016) related advantages of new products with market benefits. Interestingly, these examples of studies connect innovation as a process or a capacity with the profits of the firm and its derivation in the IO set. 
Other research, closer to our proposal, has tried to relate learning with innovation, if not directly. Several studies have analyzed that the use of knowledge, skills and capacities among the members of the organization is associated with an innovative performance (Aragón-Mendoza et al. 2016; Lansisalmi et al. 2006) and its underutilization produces poor IO. Potter and Balthazards (2004) focused their study on the destruction of learning barriers impeded by IO, and demonstrated that an interactive and constructive style of innovation improves team performance; while a passive and aggressive style reduces the result of tasks and, consequently, innovation and benefits. In Dupuy (2004) we find that it is necessary for firms to develop a "culture of innovation" that invests in the capacities of employees through learning processes at the individual, group and organizational levels. Alwis and Harmann (2008) conclude in their study that IO can be a key element for survival in crisis economies and competitive markets. Firms must ensure that their organization promotes learning and knowledge transfer for obtain IO. In the research by Alegre and Chiva (2008) the organizational learning capacity is defined from five dimensions or mechanisms, and the impact of these mechanisms on the result of innovation in product is analyzed. Finally, the results of the study by Amara et al. (2008) indicate that different types of learning impact on the presence (or absence) of innovation as well as the degree of novelty of innovation.

These examples demonstrate the growing interest in the literature for the relationship between learning and innovation, and the need to deepen their relationships in a more direct way. As we have already advanced in the introduction, it is possible to define a novel model that relates the learning flows in its two directions, Exploitation and Exploration, with the IO. The logic of the relations can be considered linear and is shown in Figure 1. As independent variables, we consider the learning flow Exploration with the IO, and as dependent variables IO and Exploitation. Specifically, we will study how Exploration affects of IO; and how IO affects on the Exploitation. 


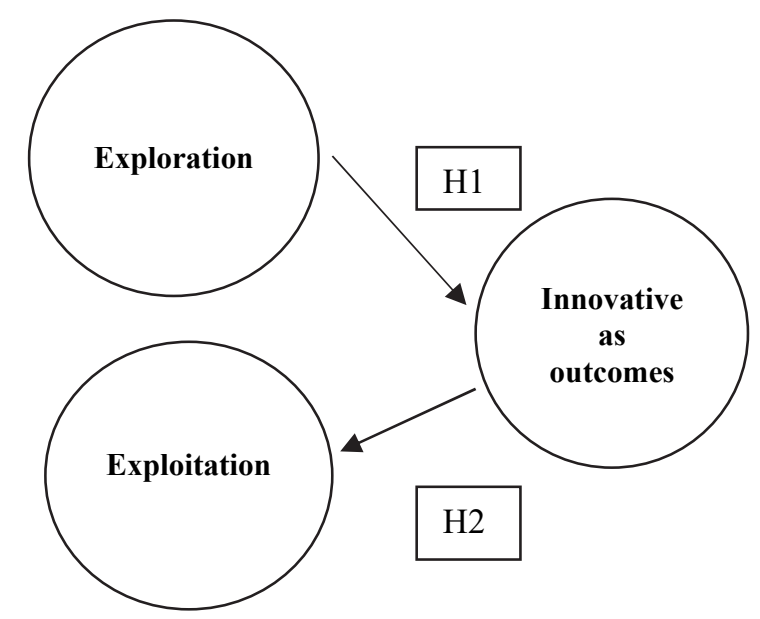

Figure 1. Model of relationships between Exploitation and Exploration and innovative outcome

\section{Research Hypotheses}

In this section, we will try to propose the hypotheses of our model that, will later be contrasted in an empirical study. The model presented is simple but novel and consists of two fundamental relationships.

The first relation we propose establishes to what extent the Exploration learning flow influences the IO. It is known that sharing knowledge among people is a form of innovation that generates new ideas and develops new business opportunities through learning processes. The relevance of the processes of knowledge sharing in innovation has been argued theoretically, however, there are few empirical studies.

Some authors consider that the interaction between individuals with different knowledge improves the organization's ability to innovate (Boland and Tenkasi 1995; Cohen and Levinthal 1990). Also, many papers argue that sharing knowledge among workers is a fundamental phase of the process of creating organizational knowledge, because if it does not perform effectively, it can be an important barrier to the development of that process and, consequently, to obtain innovation results (Chang et al., 2007; Damanpour and Shanthi 2001, Ipe 2003; Nonaka and Takeuchi 1995; vande Vrande et al. 2009).

The presence of the learning flows requires a series of characteristics that allow the firm to develop the learning processes and, consequently, to turn it into an innovative organization and should have a clear preference for either exploration or exploitation, because such an approach reduces variability in firm performance (Parida et al. 2016; Vargas et al. 2016). Innovative processes have become an indispensable prerequisite for competitive advantage and survival for organizations, and it seems especially vital for small businesses with limited resources (vande Vrande et al. 2009). There are likely to be several factors directly influencing innovations. One such background is learning (Amara et al. 2008). Innovation seems to be closely related to organizational learning, since innovation is described as an ability program to introduce and apply new ideas within the firm (Alegre and Chiva 2008). Learning can be seen as an intrinsic quality of any organizational system, as well as 
the main guide to other capacities that, likewise, condition organizational effectiveness. The higher of learning capacity of the system, greater will be the likelihood of achieving and maintaining competitiveness and success in a changing environment (Bontis et al. 2000). As already explained at the beginning of the theoretical framework, Crossan et al. (1999), developed a framework on the phenomenon of renewal. The organizational learning process involves a tension between assimilating new learning (exploration) and using that which has already been learned (exploitation).

In innovative firms, the discovery of products and development processes is a complex and multidisciplinary process, requiring efforts to access a wide range of knowledge. However, most of these firms have limited capabilities and focus, strictly, on some specific applications. Under such circumstances, business managers are forced to exploit their dynamic capabilities to reach beyond their limits in order to make changes and achieve innovative results (Teece 2012).

The exploration flows has been considered as a process involving a behavior towards flexibility, search, change, variation, risk, experimentation, discovery and innovation (Crossan and Apaydin 2010; Crossan et al. 1999). This process of experimentation can lead to the recognition of new objectives or means to achieve objectives, new ways of responding to changes in the environment, new models of stimulus-response relationship and the integration of new principles within the cognitive structures (March 1991). Moreover, at the same time, the regeneration of knowledge occurs; exploration includes the abandonment of obsolete or useless knowledge (Hedberg 1981).

Based on the above arguments, our first hypothesis can be considered as follows:

\section{H1. The Exploration has a positive effect on IO.}

Crossan et al. (1999) and Crossan and Apaydin (2010) affirm that the Exploitation is considered as a process of convergence within the organization that includes aspects such as the search for efficiency, stability, refining, reelection, production, the successful implementation of technical and administrative innovations and, in addition, provides clear and fast feedback information. Other learning studies have argued that, as a result of the Exploration and Exploitation processes, the organization obtains an adjustment with the surrounding conditions (Argyris and Schön 1978; Levitt and March 1988). Consequently, with these arguments, the strength and development of learning flows suggest that learning systems should be viewed from the point of view of their dynamic nature. Only the continuity of learning flows makes possible the dynamics of knowledge and the achievement of innovative results by closing the cycle with the exploitation of knowledge. Therefore, we can define the second hypothesis as follows.

H2. IO influences the Exploitation positively.

\section{Research Methodology}

As we have already advanced in the introduction, the sector chosen for our research has been the biotechnology sector in Spain. This innovation can be considered as a highly innovative industry, with innovation being a key 
factor in sustaining competitive advantages and the generation of learning processes (Bontis 1999; Pew et al. 2008) and creation of new knowledge (Nonaka and Takeuchi 1995). These knowledge intensive firms are a source of qualified employment, and in constant learning processes. Biotechnology firms are based on knowledge and entrepreneurial, so their most relevant resources allow them to raise their levels of knowledge and improve their innovations to sustain competitive advantages.

In the creating the questionnaire, we used a Likert scale of 7 points: (1 Very disagree-7 Very agree) (Bontis 1998). A total of 21 items were included, designed to integrate three constructs (the first one related to the Exploitation, the second corresponding to the Exploration, and the third to the innovative IO results (See Table 1). Created three scales that were validated through the analysis of individual reliability of the items (factor loads $(\lambda)$, internal consistency evaluation (Cronbach`s alpha), convergent validity analysis for the validity of the constructs by Average Variance Extracted (AVE), and discriminant validity analysis All the results indicate that the measures were valid and reliable.

The constructs and scales we construct, which we use to measure learning flows and the innovative result, have their origin in research developed by Bontis (1999); Bontis et al. (2002), Lloria and Moreno (2014), MorenoLuzón and Lloria (2008) and, Vargas and Lloria (2014), among others.

Initially, a total of 236 firms were contacted through a web application. The questionnaire was answered by the head of the firm or by the scientific director. All managers responded by completing educational studies at master's or doctoral level. The final sample size was 31 firms, with a sample error of $7.97 \%$, a response rate of $13.13 \%$ and a confidence level of $95 \%$.

\begin{tabular}{|c|c|c|c|}
\hline Construct & Objective & Ítems & Scale \\
\hline $\begin{array}{l}\text { Classification } \\
\text { Data }\end{array}$ & $\begin{array}{l}\text { To establish the profile and } \\
\text { basic characteristics of } \\
\text { the firms in the sample }\end{array}$ & $\begin{array}{l}\text { Type of organization, number of workers, } \\
\text { academic background, position in the } \\
\text { organization and gender. }\end{array}$ & \\
\hline \multirow{7}{*}{ Exploration } & \multirow{7}{*}{$\begin{array}{l}\text { To discover how the } \\
\text { learning of individuals and } \\
\text { groups affects the } \\
\text { organization's innovative } \\
\text { results }\end{array}$} & $\begin{array}{l}\text { FF1The lessons learned by your group are } \\
\text { actively shared with other members of the } \\
\text { organization. }\end{array}$ & \multirow{7}{*}{$\begin{array}{l}(1-7) \\
\text { Reflective } \\
\text { Items }\end{array}$} \\
\hline & & $\begin{array}{l}\text { FF2. The employees of the organization are } \\
\text { involved in the organization's strategy. }\end{array}$ & \\
\hline & & $\begin{array}{l}\text { FF3. Recommendations made by individuals or } \\
\text { groups are adopted by the organization. }\end{array}$ & \\
\hline & & FF4. We did not reinvent the Wheel. & \\
\hline & & $\begin{array}{l}\text { FF5. The left hand "of the organization knows } \\
\text { what the" right hand "is doing". }\end{array}$ & \\
\hline & & FF6. Individuals challenge group propositions & \\
\hline & & $\begin{array}{l}\text { FF7. The results of the group are used to } \\
\text { improve products, services, processes and } \\
\text { projects. }\end{array}$ & \\
\hline & \multirow{2}{*}{$\begin{array}{l}\text { To establish how } \\
\text { innovative knowledge } \\
\text { embedded in systems and } \\
\text { procedures affects the } \\
\text { individual and the groups }\end{array}$} & $\begin{array}{l}\text { FB1. The policies, practices and procedures } \\
\text { (routines) used in the organization are an aid to } \\
\text { the development of individual work. }\end{array}$ & \multirow{2}{*}{$\begin{array}{l}(1-7) \\
\text { Reflective } \\
\text { Items }\end{array}$} \\
\hline & & $\begin{array}{l}\text { FB2. The decisions of the group determine } \\
\text { patterns that condition or influence the } \\
\text { individuals that comprise it. }\end{array}$ & \\
\hline
\end{tabular}




\begin{tabular}{|c|c|c|c|}
\hline Construct & Objective & Ítems & Scale \\
\hline \multirow{5}{*}{ Exploitation } & \multirow[t]{5}{*}{ of the organization } & $\begin{array}{l}\text { FB3. Continuous training improves the } \\
\text { knowledge and skills of individuals and groups }\end{array}$ & \\
\hline & & $\begin{array}{l}\text { FB4. The objectives of the organization are } \\
\text { communicated to all its members. }\end{array}$ & \\
\hline & & $\begin{array}{l}\text { FB5. Company files and databases provide the } \\
\text { information needed to do the job. }\end{array}$ & \\
\hline & & $\begin{array}{l}\text { FB6. There are policies such as the rotation of } \\
\text { posts that make the development of work more } \\
\text { flexible. }\end{array}$ & \\
\hline & & $\begin{array}{l}\text { FB7. Whose decisions we make for the future, } \\
\text { we do not go back to thinking about memories } \\
\text { of the past. }\end{array}$ & \\
\hline \multirow{7}{*}{$\begin{array}{l}\text { innovative as } \\
\text { outcomes }\end{array}$} & \multirow{7}{*}{$\begin{array}{l}\text { Determine whether it has } \\
\text { been introduced into the } \\
\text { market or used within the } \\
\text { organization, innovations } \\
\text { in processes, products or } \\
\text { services or major } \\
\text { technological } \\
\text { improvements produced }\end{array}$} & $\begin{array}{l}\text { IO1. The organization promotes the search, } \\
\text { improvement and solutions to the problems of } \\
\text { the productive processes. }\end{array}$ & \multirow{7}{*}{$\begin{array}{l}(1-7) \\
\text { Reflective } \\
\text { Items }\end{array}$} \\
\hline & & $\begin{array}{l}\text { IO2. The organization has advanced technology } \\
\text { to facilitate the development of ideas and } \\
\text { creation of products and services. }\end{array}$ & \\
\hline & & $\begin{array}{l}\text { IO3. The organization has an effective ability to } \\
\text { create and defend patent processes, licenses, } \\
\text { trademarks and utility models. }\end{array}$ & \\
\hline & & $\begin{array}{l}\text { IO4. The capabilities of the organization's } \\
\text { employees (teamwork, leadership, adaptation to } \\
\text { changes, creativity) are considered as a source } \\
\text { of competitive advantage. }\end{array}$ & \\
\hline & & $\begin{array}{l}\text { IO5. Organizational employees adapt and } \\
\text { cooperate to make changes. }\end{array}$ & \\
\hline & & $\begin{array}{l}\text { IO6.The productivity of the organization has } \\
\text { increased in the last year. }\end{array}$ & \\
\hline & & $\begin{array}{l}\text { IO7. The organization has obtained licenses and } \\
\text { patents for innovative projects. }\end{array}$ & \\
\hline
\end{tabular}

Table 1. Measurement of the constructs

\section{Results}

To analyze and validate the data we use the Partial Least Square (PLS) technique. The PLS program works with a segmentation of complex models and, therefore, is an appropriate technique for exploratory research or predictive studies for small samples (Bagozzi, Yi and Singh 1991; Fornell and Bookstein 1982; Wold 1980; 1985).

Table 2 provides the loads $(\lambda)$ of most items. These values were obtained using Smart PLS 2.0 (Ringle, Wende and Will 2005). It was verified that most of the loads $(\lambda)$ of the items are higher than 0.7 (Chin, 1998). For those that did not reach this value, a debugging process was performed, proving, previously, that there was no multicollinearity problem with the new items, since Tolerance (T) and Variance Inflation Factor (FIV) were not greater than 10 (Kleinbaum and Muller 1988). In this way, a better evaluation of internal consistency and convergent validity was subsequently obtained. 
EXPLOITATION

(EXT)

$\begin{array}{llll}\text { EXT1 } & 0,8647 & 0,0000 & 0,0000 \\ \text { EXT2 } & 0,8142 & 0,0000 & 0,0000 \\ \text { EXT3 } & 0,8570 & 0,0000 & 0,0000 \\ \text { EXT4 } & 0,8138 & 0,0000 & 0,0000 \\ \text { EXT5 } & 0,7909 & 0,0000 & 0,0000 \\ \text { EXT6 } & 0,5371 & 0,0000 & 0,0000 \\ \text { EXT7 } & 0,5567 & 0,0000 & 0,0000 \\ \text { EXR1 } & 0,0000 & 0,8364 & 0,0000 \\ \text { EXR2 } & 0,0000 & 0,7076 & 0,0000 \\ \text { EXR3 } & 0,0000 & 0,7644 & 0,0000 \\ \text { EXR4 } & 0,0000 & 0,6317 & 0,0000 \\ \text { EXR5 } & 0,0000 & 0,8725 & 0,0000 \\ \text { EXR6 } & 0,0000 & 0,6320 & 0,0000 \\ \text { EXR7 } & 0,0000 & 0,8954 & 0,0000 \\ \text { IO1 } & 0,0000 & 0,0000 & 0,7070 \\ \text { IO2 } & 0,0000 & 0,0000 & 0,6657 \\ \text { IO3 } & 0,0000 & 0,0000 & 0,8666 \\ \text { IO4 } & 0,0000 & 0,0000 & 0,8479 \\ \text { IO5 } & 0,0000 & 0,0000 & 0,4561 \\ \text { IO6 } & 0,0000 & 0,0000 & 0,7956 \\ \text { IO7 } & 0,0000 & 0,0000 & 0,7584\end{array}$

EXPLORATION

(EXR)

$\begin{array}{llll}\text { EXT1 } & 0,8647 & 0,0000 & 0,0000 \\ \text { EXT2 } & 0,8142 & 0,0000 & 0,0000 \\ \text { EXT3 } & 0,8570 & 0,0000 & 0,0000 \\ \text { EXT4 } & 0,8138 & 0,0000 & 0,0000 \\ \text { EXT5 } & 0,7909 & 0,0000 & 0,0000 \\ \text { EXT6 } & 0,5371 & 0,0000 & 0,0000 \\ \text { EXT7 } & 0,5567 & 0,0000 & 0,0000 \\ \text { EXR1 } & 0,0000 & 0,8364 & 0,0000 \\ \text { EXR2 } & 0,0000 & 0,7076 & 0,0000 \\ \text { EXR3 } & 0,0000 & 0,7644 & 0,0000 \\ \text { EXR4 } & 0,0000 & 0,6317 & 0,0000 \\ \text { EXR5 } & 0,0000 & 0,8725 & 0,0000 \\ \text { EXR6 } & 0,0000 & 0,6320 & 0,0000 \\ \text { EXR7 } & 0,0000 & 0,8954 & 0,0000 \\ \text { IO1 } & 0,0000 & 0,0000 & 0,7070 \\ \text { IO2 } & 0,0000 & 0,0000 & 0,6657 \\ \text { IO3 } & 0,0000 & 0,0000 & 0,8666 \\ \text { IO4 } & 0,0000 & 0,0000 & 0,8479 \\ \text { IO5 } & 0,0000 & 0,0000 & 0,4561 \\ \text { IO6 } & 0,0000 & 0,0000 & 0,7956 \\ \text { IO7 } & 0,0000 & 0,0000 & 0,7584\end{array}$

INNOVATIVE AS OUTCOMES

(IO)

EXT: Exploitation; EXR: Exploration; IO: Innovative as outcomes

Tabla 2. Factor loadings $(\lambda)$

The evaluation of the quality of the measurement model was performed by internal consistency analysis (strict reliability level, Cronbach's alpha greater than 0.8 ), convergent validity analysis (measurements of viable and valid constructs, by obtaining the AVE) (Table 3); and discriminant validity analysis (correlations between constructs are less than the square root of the AVE) (Table 4). These analyzes demonstrate that the results satisfactorily meet the requirements established in the literature.

\begin{tabular}{|l|c|c|c|c|c|c|}
\cline { 2 - 7 } \multicolumn{1}{c|}{} & AVE & $\begin{array}{c}\text { Composite } \\
\text { Reliability }\end{array}$ & $\mathrm{R}^{2}$ & $\begin{array}{l}\text { Cronbachs } \\
\text { Alpha }\end{array}$ & Communality & Redundancy \\
\hline Exploitation & 0,7044 & 0,9225 & 0,7019 & 0,8950 & 0,7044 & 0,4902 \\
\hline Exploration & 0,6733 & 0,9108 & 0,0000 & 0,8785 & 0,6733 & 0,0000 \\
\hline $\begin{array}{l}\text { Innovative } \\
\text { as outcomes }\end{array}$ & 0,6565 & 0,9045 & 0,7600 & 0,8671 & 0,6565 & 0,4947 \\
\hline
\end{tabular}

Table 3. Indicators for assessing internal consistency and convergent validity

\begin{tabular}{|c|c|c|c|}
\cline { 2 - 4 } \multicolumn{1}{c|}{} & Exploitation & Exploration & Innovative as outcomes \\
\hline Exploitation & 1,0000 & 0,0000 & 0,0000 \\
\hline Exploration & 0,8166 & 1,0000 & 0,0000 \\
\hline Innovative as outcomes & 0,8278 & 0,8118 & 1,0000 \\
\hline AVE & 0,7044 & 0,6733 & 0,6565 \\
\hline Square root AVE & 0,8393 & 0,8205 & 0,8102 \\
\hline
\end{tabular}

Table 4. Discriminant validity 


\subsection{Structural Model and Results}

The proposed model was applied to identify the contribution between the learning flows Exploration and Exploitation with the IO. As shown in Table 5, and according to the $H 1$ hypothesis, the Exploration influences directly and positively, with a significant relation with the IO (H1): $\beta(0.872), \mathrm{R}^{2}(0.760)$, and $\mathrm{t}(29.04)$. Its positive effect demonstrates that in innovative firms with limited resources, the dynamics of the Exploration flow reorient their behaviors to stimulate the exploration of their dynamic capacities for innovative results.

In relation to the second $H 2$ hypothesis, we are surprised by the significant relationship of IO with the learning flow Exploitation; (H2): $\beta$ (0.838), $\mathrm{R}^{2}$ (0.702), and $t$ (46.7373). The result confirms the presence of a process of convergence of knowledge to the organization in a clear way, helping to develop and improve individual capacities, to restart the production cycles of new or improved products or organizational processes.

\begin{tabular}{|c|c|c|c|c|c|}
\hline Path & Hypothesis & $\beta$-path & $\mathrm{R}^{2}$ & $t$-statistics & Support \\
\hline $\begin{array}{l}\text { Innovative as outcomes - } \\
>\text { Exploitation }\end{array}$ & $H 1$ & 0.872 & 0.760 & $29.04 * * *$ & $\stackrel{n}{0}$ \\
\hline $\begin{array}{l}\text { Exploration -> Innovative } \\
\text { as outcomes }\end{array}$ & $H 2$ & 0.838 & 0.702 & $46.7373 * * *$ & $\overrightarrow{\bar{n}}$ \\
\hline
\end{tabular}

Table 5. Summary of results

We used the bootstrapping technique, with a recommended sample size of 500, to evaluate the statistical significance of the path coefficients. Table 5 shows the summary of the results of the hypotheses presented. The results of the predictive relevance of the blindfolding $\left(\mathrm{Q}^{2}\right)$ constructs (Chin, 1998; Tenenhaus et al. 2005) are positive, which certifies the predictive relevance of the model (Henseler et al. 2009). Finally, we calculated the Goodness-of-Fit (GoF) index (Tenenhaus et al. 2005). The GoF value was 0.7052 , indicating that this is a robust model, that is, as a whole, is explained properly.

\section{Discussion and conclusions}


The fundamental purpose of this research has been the empirical definition and testing of a novel relationship model between Exploration and the Innovative Result and its influence with Exploitation in entrepreneurial and innovative firms in the biotechnology sector in Spain. Although there is some research in this respect, the value of learning flows between individuals and the organization to obtain innovation outcome, as well as the complexity and associated difficulty and their adequate development, results in this area showing a special interest in research (Brachos et al. 2007, Cho 2007, Crossan and Apaydin 2010, Ganter and Hecker 2013, 2014, Sideler de alwis and Harman 2008, Teece 2012, Vargas and Lloria 2017; Vargas et al. 2016).

The results of this study have important implications for the management of innovation in organizations. This research provides the necessary evidence that learning flows increase the outcome of innovation and indirectly contribute to the acquisition of competitive advantages. This work also has implications for the literature on organizational learning. The dependent relationship between IO and Exploitation and Exploration where IO depends on the movements and dynamism of learning flows (Bontis 1999; Crossan et al. 1999).

In the theoretical framework, we have defined the Exploitation and Exploration, linked to the innovation, finding few empirical researches both quantitative and qualitative that relate these variables directly. After reviewing various definitions, and in order to be operative, we have defined Exploitation as the process of convergence that provides clear and rapid feedback to individuals and groups; The Exploitation is related to activities more oriented towards the selection and standardization of successful practices. For this reason, the activity of exploitation does not generate novelty, but stability and reinforcement of routines. On the other hand, the Exploration has been defined as the process that transforms knowledge of individuals into knowledge at the organizational level. This flow is related to exploration activities, that is, activities that transform the search space for solutions; Activities that seek to open new learning opportunities, eliminating routines and creating new ones; or activities that try to generate new problems and uncertainty. In relation to this last aspect, exploration activities transform or expand the space of solution possibilities as they relate to innovation (Crossan et al. 1999).

After the theoretical definition of the relationship model between these variables, the hypotheses have been validated in a study of a quantitative nature. The chosen sector has been Spanish firms of the biotechnology sector. An effort has been made, firstly, in the construction and validation of measurement scales for the different variables: Exploration, Exploitation and innovative as outcomes. For the construction of these scales have been considered the most relevant works, both theoretical and empirical. These scales have satisfactorily outperformed reliability, internal consistency, convergent validity, and discriminant validity.

The first result that can be drawn from our research is the overall good fit of the model. A Goodness-of-fit (GoF) of 0.7052 was obtained, indicating its optimal explanatory capacity. Likewise, all the determination coefficients $\left(\mathrm{R}^{2}\right)$ comfortably exceed $10 \%$, which implies a sufficient predictive capacity.

A second result of the empirical study is the intense relationship between learning flows: Exploitation and Exploration, and innovative as outcomes. The two hypotheses were significant, demonstrating the dynamics of the Exploration with the IO, and the cyclic movement of the IO with the Exploration.

More explicitly, and entering the detail of the model, we can conclude that the flow Exploration improves or increases IO, this shows a close relationship between Exploitation and IO (Boland and Tenkasi 1995; Cohen and 
Levinthal 1989 Crossan and Apaydin 2010, Teece 2012). It is also interesting that IO increases the Exploitation learning process. This shows that the cycle of converting innovative knowledge into organizational innovation is complemented by selecting and standardizing successful processes that generate competitive advantage in innovative sectors (Crossan and Bendrow 2003; Crossan et al. 1999; Damanpour and Aravind 2012; JiménezJiménez and San-Valle 2011; Parida et al. 2016; Ren et al. 2016).

To conclude, we emphasize that the main limitation of our research comes from the size of the sample. The sector studied is formed by firms with emerging processes, shaken by a global economic crisis. Some managers were unwilling to collaborate or were reluctant to overload their work and lack of time to complete the questionnaire. In principle, this was not a problem because the PLS technique has been used for empirical research with small samples over the last two decades and these works have been published in prestigious journals (Demartini 2015; Ringle et al. 2012).

Finally, the results of this study provide future research lines. A first and immediate investigation would be to study, in the same model, the impact of relations in a different direction. For example, assess the impact of Exploitation on IO. Another very different possible way of investigation would be to confirm the applicability of the results obtained to other types of industries that differ substantially from the industry evaluated. Finally, a future line of research is to apply novel methods developed from the signal processing on graphs framework to the problem proposed in this work. Recently, these methods have shown interesting results in data analysis for several applications that could complement the ones obtained by traditional statistical methods (see for instance, Belda et al. 2017; Vergara et al. 2017).

\section{Acknowledgments}

This work was supported by Universitat Politècnica de València (Proyectos Internos de Investigación de las Estructuras de I+D). In addition, was supported by Spanish Ministry of Economy, Industry and Competitiveness and the State Research Agency. Co-financed by the European Regional Development Fund (ERDF), under project ECO2015-71380-R.

\section{References}

Amara, N., Landry, R., Becheikh, N., \& Ouimet, M. (2008). Learning and novelty of innovation in established manufacturing SMEs. Technovation, 28, 450-463.

Alegre, J., \& Chiva, R. (2008). Assessing the impact of organizational learning capability on product innovation performance: an empirical test. Technovation, 28, 315-326.

Aragón-Mendoza, J., Pardo del Val, M., \& Roig, S (2016.) The influence of institutions development in venture creation decision: A cognitive view. Journal of Business Research, 69(11), 4941-4946.

Argyris, C., \& Schön, D. (1978). Organizational Learning: A theory of action perspective. Addison Wesley, Reading, MA. 
Ardichvili, A. (2008). Learning and knowledge sharing in virtual communities of practice: motivators, barriers, and enablers. Advances in Developing Human Resources, 10(4), 541-554.

Bagozzi, R.P., Yi, Y., \& Singh, S. (1991). On the use of structural equation models in experimental designs: two extensions International. Journal of Research in Marketing, 8, 125-140.

Belda, J., Vergara L., Salazar, A., \& Safont G. (2017). Surrogate Time Signals Using Graph Signal Processing, submitted to IEEE Transactions on Signal Processing, 2017.

Bontis, N., Dragonetti, N.C., Jacobsen, K., \& Ross, G. (1999). The knowledge toolbox: a review of the tools available to measure and manage intangible resources. European Management Journal, 17, 391-402.

Bontis, N. (1999). Managing an organizational learning system by aligning stocks and flows of knowledge: An empirical examination of intellectual capital, knowledge management, and business performance. 1999. Management of Innovation and New Technology Research Centre, McMaster University.

Bontis, N., Hullan, J., \& Crossan, M. (2002). Managing an organizational learning system by aligning stocks and flows. Journal of Management Studies, 39, 438-469.

Boland, R. J. J., \& Tenkasi, R. V. (1995). Perspective making and perspective taking in communities of knowing. Organization Science, 6(4), 350-372.

Brachos, D., Kostopulos, K., Sodersquist, K. E., \& Prastacos, G. (2007). Knowledge Effectiveness, Social Context and Innovation. Journal of Knowledge Management, 11(5), 31-44.

Calantone, R. J., Cavusgil, S. T., \& Zhao, Y. (2002). Learning orientation, firm innovation capability, and firm performance. Industrial Marketing Management, 31, 515-24.

Cooper, R. G. (2000). New product performance: what distinguishes the star products. Austrian Journal of Management, 25, 17-45.

Cohen, W. M., \& Levin, R. C. (1989). Empirical studies of innovation and market structure. In Schmalansee, R. and Willing, R. D. (Eds), Handbook of Industrial Organization II. New York: Elsevier.

Cohen, W. M., \& Levinthal, D. A. (1990). Absorptive-capacity - a new perspective on learning and innovation. Administrative Science Quarterly, 35, 128-52.

Crossan, M., Lane, H.W., \& White, R.E. (1999). An Organizational Learning Framework: From Intuition to Institution. Academy of Management Review, 24, 522-537.

Crossan M. \& Apaydin, M., (2010). A Multi-Dimensional Framework of Organizational Innovation: A Systematic Review of the Literature. Journal of Management Studies, 47(6), 1154-1191.

Cho, N., Li, G., \& Su, Ch. (2007). An empirical study on the effect of individual factors on knowledge sharing by knowledge type. Journal of Global Business and Technology, 3(2), 1-15.

Chang, T. J., Yeh, S. P., \& Yeh, I. J. (2007). The Effects of Joint Rewards System in New Product Development. International Journal of Manpower, 28(3/4), 276-297.

Chin, W. (1998). The partial least square approach to structural equation modeling, in: GA Marcoulides, ed. (Lawrence Erlbaum Associates, New Jersey). 294-336. 
Cummings, J. N. (2004). Work groups, structural diversity, and knowledge sharing in a global organization. Management Science, 50(3), 352-364.

Damanpour F., \& Shanthi G. (2001). The dynamics of the adoption of products and process innovations in organizations. Journal of Management Studies, 38(1), 21-65.

Damanpour, F., \& Aravind, D. (2012). Managerial innovation: Conceptions, processes, and antecedents. Management and Organization Review, 8(2), 423-454.

Davila, T., Epstein, M. J., \& Shelton, R. (2006). Making Innovation Work: How to Manage It, Measure It, and Profit from It. New Jersey: Wharton School Publishing, Pearson Education Inc.

Demartini, C. (2015). Relationships between Social and Intellectual Capital: Empirical Evidence from IC Statements. Knowledge and Process Management, 22(2), 99-111.

Decarolis, D.M., \& Deeds, D.L. (1999). The Impact of Stock and Flows of Organizational Knowledge on Firm Performance: An Empirical Investigation of the Biotechnology Industry. Strategic Management Journal, 20, 953-968

Dupuy, F. (2004). Sharing knowledge: They why and how of organizational change, Hampshire, UK: Palgrave Macmillan.

Fornell, C., \& Bookstein, F.I. (1982). Two structural equation models: LISREL and PLS applied to consumer exit-voice theory. Journal of Marketing Research, 19, 440-452.

Ganter, A., \& Hecker, A. (2013). Deciphering antecedents of organizational innovation. Journal of Business Research, 66(5), 575-584.

Ganter A., \& Hecker, A. (2014). Configurational paths to organizational innovation: qualitative comparative analyses of antecedents and contingencies. Journal of Business Research, 67, 1285-1292.

Gopalakrishnan, S., \& Damanpour, F. (1997). A review of innovation research in economics, sociology and technology management. International Journal of Management Science, 25, 15-28.

Hedberg, B. (1981). How Organizations Learn and Unlearn, in: P. Nystrom and W.Starbuck, eds., Handbook of Organizational Design (Oxford University, New York).

Hedlund, G., \& Nonaka, I. (1993). Models of knowledge management in the west and Japan, in: P.Lorange, B.Chacravrarthy, J.Ross, and J.Van de ven, eds., (Basil Blackwell, Cambridge).

Henseler, J., Ringle, C.M., \& Sinkovics, R.R. (2009). The use the partial least squares path modeling, in: R.Sinkovics and N.Pervez, eds. 277-319.

Hsu, I. (2006). Enhancing employee tendencies to share knowledge-Case studies on nine companies in Taiwan. International Journal of Information Management, 26 (4), 326-338.

Hsu, I. (2008). Knowledge sharing practices as a facilitating factor for improving organizational performance though human capital: a preliminary test. Expert Systems with Application, 35, 316-1326.

Huang, Q., Davison, R., \& Gu, J. (2008). Impact of personal and cultural factors on knowledge sharing in China. Asia Pacific Journal Management, 25(3), 451-471. 
Ibarra, H. (1993). Network centrality, power, and innovation involvement - determinants of technical and administrative roles. Academy of Management Journal, 36(3), 471-501.

Iebra, I. L., Zegarra, P. S., \& Zegarra A. S. (2011). Learning for sharing: an empirical analysis of organizational learning and knowledge sharin. International Entrepreneurship Management Journal, 7, 509-518

Ipe, M. (2003). Knowledge Sharing in Organizations: A Conceptual Framework. Human Resource Development Review, 2(4), 337-359.

Jiménez-Jiménez D., \& Sanz-Valle, R. (2011). Innovation, organizational learning, and performance. Journal of Business Research, 64, 408-417.

Jenkin T. (2013). Extending the 4I Organizational Learning Model: Information Sources, Foraging Processes and Tools. Administrative Sciences, 3, 96-109.

Kane, G.C., \& Alavi, M. (2007). Information Technology and Organizational Learning: An Investigation of Exploration and Exploitation Processes. Organization Science, 18(5), 796-812.

Kleinbaum, D.G., Kupper, N.N., \& Muller, K.E. (1988). Applied Regression Analysis and other Multivariable's Methods, PWS KENT.

Klomp, L., \& Van Leeuwen, G. (2001). Linking innovation and firm performance: a new approach. International Journal of the Economics of Business, 8(3), 343-364.

Laperrière, A., \& Spence, M. (2015). Enacting international opportunities: The role of organizational learning in knowledge-intensive business services. Journal of International Entrepreneurship, 13(3), 212-241.

Levitt, B., \& March, J.G. (1988). Organizational Learning. Annual Review of Sociology, 14, 319-340.

Lin, H. (2007). Knowledge sharing and firm innovation capability: an empirical study. International Journal of Manpower, 28(3/4), 315-332.

Lloria M.B., \& Moreno-Luzón, M.D. (2004). Organizational learning: Proposal of an integrative scale and research instrument. Journal of Business Research, 67, 692-697.

March, J.G., (1991). Exploration and exploitation in organizational learning. Organizational Science, 2, 71-87.

Matikainen , M., Terho, H., Parvinen, P., \& Juppo , A. (2016). The role and impact of firm's strategic orientations on launch performance: significance of relationship orientation. Journal of Business \& Industrial Marketing, 31(5), 625-639.

Moreno-Luzón, M.D., \& Lloria B. (2008). The role of non-structural and informal mechanisms of integration and integration as forces in knowledge creation. British Journal of Management, 19, 250-276.

Moskaliuk, J., Bokhorst, F., \& Cress, U. (2016). Learning from others' experiences: How patterns foster interpersonal transfer of knowledge-in-use. Computers in Human Behavior, 55, 69-75.

Mone, MA., McKinley, W., \& Barker, V. L. (1998). Organizational decline and innovation: a contingency framework. Academy of Management Review, 23, 115-32. 
Nonaka, I., \& Takeuchi, H. (1995). The Knowledge-Creating Company. How Japanese Companies Create the Dynamics of Innovation (Oxford University Press, New York).

Nonaka, I., \& von Krogh, G. (2009). Perspective Tacit Knowledge and Knowledge Conversion: Controversy and Advancement in Organizational Knowledge Creation Theory. Organization Science, 20(3), 635-652.

Parida V., Lahti, T., \& Wincent, J. (2016). Exploration and exploitation and firm performance variability: a study of ambidexterity in entrepreneurial firms. International Entrepreneurship Management Journal, 12, 11471164.

Pew, H., Plowman, D., \& Hancock, P. (2008). The involving research on intellectual capital. Journal of Intellectual Capital, 9, 585-608.

Ramadani, V. Hyrije. A.A., Léo-Paul, D. Gadaf, R., \& Sadudin, I. (2017). The impact of knowledge spillovers and innovation on firm-performance: findings from the Balkans countries. International Entrepreneurship Management Journal, 13, 299-325.

Ren, S., Shu, R., Bao, Y., \& Chen, X. (2016). Linking network ties to entrepreneurial opportunity discovery and exploitation: the role of affective and cognitive trust. International Entrepreneurship and Management Journal, $12(2), 465-485$.

Tansky, J.; Ribeiro, D., \& Roig, S. (2010). Linking entrepreneurship and human resources in globalization. Human Resource Management, 49(2), 217-223.

Ringle, C. M., Wende, S., \& Will, A. (2005). Smart PLS 2.0 (M3) beta, Hamburg: http://www.smartpls.de Ringle, C.M., Sarstedt, M., \& Straub, D. (2012). A critical look at the use of PLS-SEM. MIS Quarterly, 36(1), iii-xiv.

Roos, G., \& Roos, J. (1997). Measuring your company`s intellectual performance. Long Range Planning, 30, 413-426.

Sanchez, R., \& Heene, A. (1997). A Competence Perspective on Strategic Learning and Knowledge Management. En Sanchez, R. and Heene, A. (eds.) Strategic Learning and Knowledge Management, John Wiley and Sons.

Seidler-de Alwis, R., \& Hartmann, E. (2008). The use of tacit knowledge within innovative companies: knowledge management in innovative enterprises. Journal of Knowledge Management, 12(1), 133-147.

Shrivastava, P. (1983). A typology of organizational learning systems. Journal of Management Studies, 20, 7-28.

Teece, D. (2012). Dynamic Capabilities: Routines versus Entrepreneurial Action. Journal of Management Studies, 49(8), 1395-1401.

Tenenhaus, M., Vinzi, V., Chatelin, Y., \& Lauro, C. (2005). PLS path modeling. Computational Statistics and Data Analysis, 49, 159- 205.

vande Vrande, V., de Jong, J., Vanhaverbeke, W., \& Rochemont, M. (2009). Open innovation in SMEs: Trends, motives and management challenges. Technovation, 29, 423-437. 
Vargas, N., \& Lloria, M.B (2014). Dynamizing Intellectual Capital through enablers and learning flows. Industrial Management and Data Systems, 114(1), 2-20.

Vargas, N., Lloria, M.B., \& Roig-Dobón, S. (2016). Main drivers of human capital, learning and performance. The Journal of Technology Transfer, 41(5), 961-978.

Vargas, N., \& Lloria, M.B. (2017). Performance and Intellectual Capital: How Enablers Drive Value Creation in Organisations. Knowledge and Process Management, 24(2), 114-124.

Vergara, L., Salazar, A., Belda, J., Safont, G., Moral, S., \& Iglesias, S. (2017). Signal Processing on Graphs for Improving Automatic Credit Card Fraud Detection", Proceeding of 2017 IEEE 51st International Carnahan Conference on Security Technology (ICCST 2017), Madrid, Spain.

Von Krogh, G., \& Ichijo, K., Nonaka, I. (2000). Enabling Knowledge Creation, Oxford University Press.

Wang, C. L., \& Ahmed, P. K. (2004). Linking innovation and firm performance: a new approach. European International Journal of Technology Management, 27, 674-88.

Wallin M. W., \& Von Krogh, G. (2010). Organizing for Open Innovation: Focus o the Integration of Knowledge. Organizational Dynamics, 39(2), 145-154.

Wolfe, R. A. (1994). Organizational innovation - review, critique and suggested research direction. Journal of Management Studies, 31, 405-31.

Wold, H. (1980). Model construction and evaluation when theoretical knowledge is scarce. In Evaluation of Econometric Models, J. Kmenta and J.B., Ramsey, eds, Academic Press, 47-74.

Wold, H. (1985). Factors influencing the outcome of economic sanctions. In Sixto Ríos Honorary. Trabajos de Estadística and de Investigación Operativa, 36(3), 325-337.

Zampetakis, L. A., Lerakis, M., Kafetsios, K., \& Moustakis, V. S. (2016) The moderating role of anticipated affective ambivalence in the formation of entrepreneurial intent. International Entrepreneurship and Management Journal, 12(3), 815 - 838. 